\title{
CONDITIONS OF TEACHING AND RESEARCH IN ECONOMICS Some Preliminary Findings
}

\author{
S. M. NASEEM* \\ Sarfraz K. QURESHI \\ Rehana SIDDIQUI
}

* Dr. S.M. Naseem was formerly with ESCAP. Dr. Sarfraz K. Qureshi is Director, Pakistan Institute of Development Economics (PIDE), Islamabad. Dr. Rehana Siddiqui is Senior Research Economist at PIDE, Islamabad. 


\section{CONDITIONS OF TEACHING AND RESEARCH IN ECONOMICS: Some Preliminary Findings}

\section{INTRODUCTION}

This paper reports on the preliminary findings of a study initiated two years ago, at the initiative of the P.I.D.E. to review the problems of teaching and research in economics and related subjects (ERS)1 during the last two decades. The need for such a study has been felt for some time not only because of the common perception of declining standards in higher education generally and, economics, in particular, but also from the perceived competition economics has faced from other disciplines, especially buiness studies and computer science as a passport to the job market.

After having enjoyed a relatively robust period of growth in the 1960s largely through the assistance of foreign donors such as the Ford Foundation, ERS in Pakistan have suffered in their development not only from the comparative paucity of resources allocated to them, but also as a result of an adverse change in the perceptions about the primacy of their usefulness for policy purposes. The demand for economics has also suffered some decline as a result of the diminished importance of the public sector and of planned development during the last two decades. While special branches of economics, such as finance, project evaluation, transport and energy economics have shown increased demand, mainly in the private sector or donor-related institutions, the demand for general economic analysts is not as strong as in the past and does not provide many gainful opportunities for professional advancement. Due to the continued disadvantage in terms of salaries and other rewards, the academic profession, remains unattractive.

A cursory survey of the research and academic institutions in the field of ERS established both within the universities and outside, since independence is sufficient to justify the need for an in-depth study of the malaise affecting both teaching and research in economics. While some of the research institutions are relatively well endowed with human and other resources and have even acquired an international reputation, the system as a whole has failed to deliver a continuing stream of high quality research in areas of changing relevance to the economy and to provide well-trained economists to users in the government and the private sector.

The main objective of the present study was, therefore, to identify the causes of decline in quality of graduates and researchers in economics and identify possible solutions. The study has relied on both direct interviews with the institutions and on two small questionnaires, one for educational institutions and one for research organizations employing economists. We were able to visit about a dozen institutions and sent the questionnaires to twenty four educational institutions and research organizations. However, the response rate for the questionnaires was not very encouraging, as less than half the organizations responded. The study's scope was limited as the funds needed for a full-scale study could not be obtained from potential sponsors and the P.I.D.E. funded the travel and related costs from its regular budget. Both the lack of support by sponsors to fund such a study and the poor response to the questionnaire reflects the apathy in the profession and its institutions towards common issues beyond the scope of immediate concerns. 
Since it seemed unlikely that the project could be carried on much further without a more formal and concerted effort, it was decided to present its preliminary results in order to evoke wider interest and provide a basis for discussion of the underlying issues. In order to make it self-contained, the paper is structured in the following way. The next section tries to focus on the sources of demand and supply for economics teaching and research during the last two decades. The third and fourth section survey the state of education and research in the universities and research organisations, respectively. The fifth section tries to put forward some suggestions for improvements in the present structure of academic and research institutions in the economic field. The last section points out the gaps in the present study and the need for more comprehensive work in this area.

\section{THE SOURCES OF SUPPLY AND DEMAND FOR ECONOMIC EXPERTISE}

While an important part of the supply of economic expertise in Pakistan has resulted from foreign training at the graduate level, the higher educational system of the country will continue to be the most important and reliable source. In Pakistan, the number of universities and total enrollment has increased substantially during last fifty years. The number of universities has gone up from 4 in 1960 to 25 in 1997 (for recent data see table-1). The enrollment increased from 4870 students in 1960 to 71819 in recent years, however, the expansion in female enrollment is much higher. Similarly, the number of teachers has expanded very rapidly. These numbers show a rapid expansion in supply of and demand for higher education. However, the expansion in the supply has generally been at the expense of quality of graduates at the higher level, due to resource constraints and due to decline in the quality of inputs. This erosion seems to had a more pronounced effect on the social science disciplines, of which economics is an important part.

Table 1: Data on Higher Education

\begin{tabular}{|c|c|c|c|c|c|}
\hline \multirow[t]{2}{*}{ Years } & \multirow{2}{*}{$\begin{array}{c}\text { No. of } \\
\text { Universities }\end{array}$} & \multicolumn{2}{|c|}{ No. of Students Enrolled } & \multicolumn{2}{|c|}{ No. of Teachers } \\
\hline & & Total & Females & Total & Females \\
\hline 1959-60 & 4 & 4092 & 778 & 382 & 31 \\
\hline 1990-91 & 22 & 61,857 & 11,667 & 4,744 & 640 \\
\hline 1991-92 & 23 & 65,944 & 12,727 & 4,926 & 674 \\
\hline 1992-93 & 23 & 68,301 & 14,856 & 5,728 & 747 \\
\hline 1993-94 & 24 & 69,085 & 15,564 & 5,995 & 793 \\
\hline 1994-95 & 24 & 70,263 & 16,628 & 6,396 & 846 \\
\hline 1995-96 & 24 & 71,441 & 17,692 & 6,797 & 899 \\
\hline 1996-97 & $25 *$ & 71,819 & 17,956 & 6,998 & 952 \\
\hline Annual growth rate(1990-97) & 2.13 & 2.49 & 7.19 & 6.48 & 6.62 \\
\hline
\end{tabular}

The universities are gradually losing their standings as institutions of higher learning, particularly in the fields of economic and related subjects. The only area showing some signs of progress is the area of business studies after the initiation of economic liberalization programs in the early 1990s. But this expansion has been largely brought about in an unsustainable way through the engagement of part time teachers and an influx of foreign trained MBAs. 
After having enjoyed a relatively robust period of growth in the 1960s largely through the assistance of foreign donors such as the Ford Foundation, ERD in Pakistan have suffered in their development not only from the comparative paucity of resources allocated to them, but also as a result of an adverse change in the perceptions about the primacy of their usefulness for policy purposes.

A much more serious question being faced in the development of ERS in Pakistan is the steady deterioration of higher education. It is a common perception that the quality of higher education, in general, and in the social science fields in particular has declined sharply. Centres of higher learning especially in economics, are gradually losing the well-trained and qualified staff through the process of both, internal and external brain drain. Even those who have been able to resist monetary temptations are discouraged by the deteriorating administrative financial and disciplinary environment in the university.

A major constraint in the improvement of standards of teaching and research in economics is the availability of qualified staff. Table- 2 shows the changes in the number and composition of staff in seven universities and three research institutions which responded to our questionnaire. It also reports on the number of students in postgraduate economics classes in the seven universities. While there has been a significant increase in both teaching and research staff, as well as the number of students, the student teacher ratio has risen somewhat. However, in two major institutions, QAU and Government College, Lahore, where the self-financing scheme has been introduced, the ratio has risen sharply. Thus in the QAU, the number has risen from 6.2 to 16.7 as a result of a fourfold increase in the number of students and only $50 \%$ increase in the number of teachers. In the Government College, although there has been only a moderate $(12.5 \%)$ increase in the number of students, this has been accompanied by a $30 \%$ fall in the number of teachers.

In terms of the quality of staff, the ratio of Ph.D. staff members to total staff members in all the ten institutions has increased from 20.3 percent to $22.8 \%$, indicating that only a little over a fifth of all economists in the profession have Ph.D. degrees. What is interesting, however, is that this ratio is considerably higher in teaching than in research institutions. This is largely due to the low ratio of Ph.D. staff in the State Bank of Pakistan's research department, which has fallen considerably over the years. The ratio among university teachers although high has remained stagnant. More detailed analysis of individual institutions is undertaken below, based on direct personal interviews of 13 different educational and research institutes (list is given in the appendix-A) and clarifies some of the reasons for the trends noted above.

\section{DEMAND CONDITIONS}

While supply conditions have been perceived to be important in explaining the deterioration of standards, the changing nature in the demand for economic expertise has received less attention. As the economy has become less dependent on the public sector and public policy, the Governmental demand for economic expertise has declined both in terms of quantity and quality. Public "policy management" has become more an art than a science, with only a minimal technical knowledge and understanding of economics, but with a greater capacity to formulate workable policies. This narrow utilitarian view has 
done great harm to the economic profession and has adversely affected the demand for economic expertise in Governmental decision-making. The substitution of domestic economic expertise, which requires considerable academic training and research, by the generalist civil servant, who prefers to rely on his intuition or the advice of a foreign expert, in the formulation and implementation of sustainable policies has greatly diminished the role of domestic economic professionals. Another reason for the decline in the demand for economists in recent years has been the slowdown in the growth of the economy and the expansion of rent-seeking and unorganised activities which do not have much use for economic expertise. While private sector activities both in the economy at large and in the educational sector in particular have increased substantially, they have not yet realised the need for engaging highly trained economists or of conducting sophisticated economic research.

Table 2. Quantitative Indicator of Teaching of Economics

\begin{tabular}{|c|c|c|c|c|c|}
\hline & & \multicolumn{2}{|c|}{ Number of Teachers } & \multicolumn{2}{|c|}{$\begin{array}{c}\text { No. of Students } \\
\text { (M.A. and M.Phil.) }\end{array}$} \\
\hline & & 1975 & 1995 & 1975 & 1995 \\
\hline 1. & Quaid-I-Azam University $\quad 8(5)$ & $12(8)$ & 50 & 200 & \\
\hline 2. & Government College, Lahore & $10(4)$ & $7(4)$ & 80 & 90 \\
\hline 3. & University of Punjab $7(1)$ & $9(2)$ & 125 & 130 & \\
\hline \multicolumn{6}{|c|}{ 4. Institute of Development Studies, Agricultural University, } \\
\hline & Peshawar & $6(1)$ & $14(7)$ & - & 10 \\
\hline 5. & State Bank of Pakistan* $36(5)$ & $85(2)$ & - & - & \\
\hline & University of Peshawar $\quad 6(1)$ & $15(2)$ & 80 & 124 & \\
\hline 7. & Gomal University, D.I. Khan & - & $10(0)$ & - & 50 \\
\hline 8. & Pakistan Institute of Development Economics & $46(7)$ & $49(21)$ & - & - \\
\hline 9. & Sind Agricultural University, Tandojam & $9(2)$ & $9(2)$ & - & - \\
\hline & University of Arid Agriculture, Rawalpindi & - & $5(1)$ & & 50 \\
\hline & Total & $128(26)$ & $215(49)$ & 335 & 654 \\
\hline & Teaching & $40(13)$ & $81(26)$ & & \\
\hline & Research & $88(13)$ & 134(23) & & \\
\hline & Ph.D./Staff Ratio & $20.3 \%$ & $22.8 \%$ & & \\
\hline & Student/Teacher Ratio & & & 8.4 & 8.6 \\
\hline & Ph.D./Teaching Staff Ratio & $32.5 \%$ & $32.0 \%$ & & \\
\hline & Ph.D./Research Staff Ratio & $14.8 \%$ & $17.2 \%$ & & \\
\hline
\end{tabular}

For State Bank of Pakistan and Pakistan Institute of Development Economics, we have number of researchers not number of teachers.

The number in parenthesis represent members with a Ph.D degree.

\section{THE TEACHING CONDITIONS IN PAKISTANI UNIVERSITIES2}

\section{Faculty}

A pervasive problem facing most of the educational institutions in Pakistan is that they are not able to retain good teaching staff because of inadequate incentive structure. Among the worst affected has been the University of Karachi, which has suffered a serious erosion of its teaching cadre during the last two decades. At the present time, there is a dearth of senior teaching staff and the faculty does not have any full Professor or Ph.D. Most of the senior teachers have either retired or have left for 
lucrative jobs abroad or elsewhere in Pakistan. One of the major reasons for the decline in the teaching staff is the that of the non-return of the faculty members who went abroad on scholarships for foreign training. The price for this is, unfortunately being paid for by current faculty members as a result of the discontinuation of leave and scholarship to them, which has made the teaching profession even more unattractive.

Another source of hemorrhage of good faculty members has been the emergence of private universities and educational institutions who offer considerably more attractive packages of remuneration to the teachers. Although they do not provide the security of service and other facilities, the economic incentives are sufficient to attract them. The university has tried to give some financial incentives to the teachers by involving them in teaching in the self-financing programmes, where the teachers receive at least Rs.400 per lecture, it can sometimes raise the teacher's salary to 80 percent of the regular pay. The current faculty of the Department of Economics at Karachi University is mostly at the junior level and their educational qualifications is either local M.Sc. or M.Phil degree or a foreign masters degree.

Another problem being faced by many universities where senior faculty members have left a vacuum is the problem of lack of academic leadership. In some case, one or two senior faculty members who are still working do not have the academic or research credentials to inspire the confidence of their younger colleagues, while the latter are denied the opportunities to develop a leadership from among themselves. Often this has led to in-fighting among faculty members which diverts attention from academic and research work and takes a heavy toll in terms of lack of motivation

Despite the fact that enrollment in economics has not increased at a very high rate, the studentteacher ratio has increased in most universities. This increase in burden of teaching not only discourages teachers to undertake research, it also results in ability of teachers to improve their stock of knowledge and improve their teaching .

The promotion criteria for teaching staff at colleges and universities differ. The college teacher is promoted on the basis of years of services whereas for university teacher the publications are also required. As a result sometime college teacher with same qualifications get promoted before the university teachers (see table A-I also).

Ban on recruitment has also deteriorated the availability of teacher and the quality of teaching staff. In some instances it was reported that the previously they were able to hire good teachers from other educational institutions in case of teacher shortage in a particular field of economics. Now this option is not available to the colleges and universities.

\section{B. Students}

One of the important questions that we were interested in learning from the project is whether economics continues to enjoy the strong preference of students with high academic standing. On this, the evidence was mixed. The perception of teachers about the quality of students varied across educational institutions. For example, at LUMS the quality of the incoming student has not changed significantly. In fact, the quality of these students is better and people are paying for the quality 
teaching. Consequently, the graduates of LUMS are quickly absorbed in the job market. In Punjab University, on the other hand, the quality of incoming students opting for economics seems to have declined over time but it is still better than in many other disciplines. For the 75 seats in the M.A. classes in economics, the University receives over 1000 applications. At the IDS, Peshawar, Economics did not rank as high as business administration and computer sciences in the preference ordering of the students entering the university. As a result the quality of the students coming to the economics department seems to be falling over the years. For instance, whereas a majority of students entering the IDS programme in the beginning had First Class in their B.Sc., currently, only 2 to 3 first class students were applying for admission in economics.

A related issue was the employment preference of economics M.A.s. The trend for employment seems to have shifted from CSS to private sector employment. Academic jobs were less preferred to other government and private employment, while research was considered inferior to teaching in career preference of students and as well as in public perception. If a generalisation could be made on this limited evidence, it would seem that the preference of the students is correlated with the perception of the quality of teaching in an institution. It may also be the case that students with access to publicly funded institution have different career goals than those entering private institutions.

The decline in the quality of the students entering the Masters degree programme in economics was also a reflection of the poor quality of graduates coming out from the colleges. The existence of two separate medium of instructions namely, English and Urdu medium, was also responsible for a fall in the average quality of the students. It seems that a higher proportion of Urdu medium students were now entering the University than in the past, since the better trained English medium students were syphoned off to business administration and other disciplines. Schemes for remedial courses to improve the average quality of students need to be devised to correct the situation. Another reason cited for the decline in the preference for economics was becoming more technical and mathematical.

One interesting finding, especially brought out in the interview with the Government College, Lahore, faculty, is that the gender composition in the field of economics has changed significantly, both quantitatively and qualitatively. In the Government College, where students are admitted on merit, 90\% of the successful candidates are girls. The number of applications for girls has not changed but their performance has improved. In fact the number of applications for boys has declined as they opt for commerce, business administration and computers science.

Other reasons for the decline in the quality of the students which emerged from discussions with our academic colleagues are briefly listed below;

I) Lack of Reading Habits: The reading habits are not instilled. The students study just to pass the examination. This has adversely affected the development of intuitive thinking and creative talents.

ii) Discipline: Lack of Discipline, in general, is affecting not only the quality of students but also the working environment in the universities. This lack of discipline with lack of motivation is the major constraint in producing good economic graduates. 
iii) Library: The Libraries do not have updated reading material, because of in sufficient funding. For example, Government College, Lahore received only Rs.10,000/- for library funding this year.

iv) Research Orientation: The need for professional economists is evident. But due to lack of research orientation at the educational institutions the supply of indigenous trained economists is inadequate.

v) Student-Teacher Interaction: The interaction among the teaching community and students is minimum. The increase in student teacher ratios has made it difficult to develop such a linkage and to reap the benefits of effective small group teaching.

vi) Curriculum: What and how economics is taught today? These are important issues. So far there is no standard and updated curriculum for students. The curriculum should be developed in such a way that it reflects the changing needs and developments in the subject, and it should improve the employability of economic graduates.

vii) Examination System: Use of unfair means to pass the examination, rote of sample questions and $100 \%$ choice in the examination are the major problems in our examination system. Since determine the merit of the student use of unfair means to pass exams is rising. However, despite these unfair practices the pass percentage is low in the field of economics.

viii) Political interference: The student are attached to political parties, which affects work environment and discourages the serious community to take active role in teaching. This also disrupts the process of learning and causes significant loss in terms of time and money.

\section{SOLUTIONS:}

In order to improve the situation, following suggestions were made:

I) Incentive Structure: The teachers should be offered better salary structure, so that they can concentrate on teaching and the educational institutions do not suffer from brain drain.

ii) Teachers Training: Arrange refresher courses for teachers, which can help them to learn modern methods of teaching and communicating with students. By improving the quality of teaching methods the teachers can make learning economics challenging and interesting. This could be done by arranging workshops and refresher courses.

iii) Self-Financing Schemes: The self-financing scheme may offer some resources to the educational institutions which can be used to improve the teaching environment. The Punjab University has started self-financing for 10-15\% of the student in the class. The self-financing scheme, however, involves a considerable amount of additional work and integration which is often undertaken at the expense of teaching the regular classes. Another problem with the self- 
financing scheme is that since most of the students pay a high fee, they expect the teaching to be of a level that would ensure their success in examination. However, since the students admitted to the self-financing programme are those of a lower caliber than in the regular classes, a percentage of them do not in fact clear the exam.

iv) Updating the curriculum: In this regard UGC can play an important role. Either they and try to implement quality curriculum or they can give more independence to educational institutions to develop their own curriculum with the supervision of UGC.

By standardizing and updating the curriculum we can incorporate the recent changes in the global economic environment and the extensions in the subjects of economics. This will help us to enhance efficiency and effectiveness of education of economics. This will also enable the students to think like an economist.

v) Examination System: In order to improve the examination system, we can develop internal examination system - like performance in college attendance and in class room. The incoming students should be evaluated by university.

We can have centralized system of examination like banking council examination at the end of the university education. Furthermore, there is an urgent need to control the use of unfair practices in the examination.

vi) Autonomy of Universities: Universities should be able to set up their own policies regarding admission, curriculum, hiring of teaching staff and examinations system. Now the emphasis should be on what is taught, how it is taught and its relevance to the job market. The primary responsibility is that of universities as Kabra (1996) emphasizes that. "Let the universities become agents of social transformation based on the relative autonomy of social scientists and scholars and intellectual workers.

vii) Incentive Structure: The performance based reward system should be introduced for teachers and researchers.

viii) Research Funding: In order to promote research, grants should be given to the teacher/researchers. In regard to resources, there seems to be no increase in resources to hire senior researchers/faculty member. There was also very limited allocation of resources for computers and other research requirements. The University has a policy of not supporting any research which is not funded by other agencies. Thus there is considerable dependence on the funding from external donor agencies to conduct research. Traditionally, the government research organizations face competition from private consulting firms for external funding and often private sector gets the project because they are better endowed with resources. Sometimes the government research Institute and the University staff work clandestinely for such consulting funds.

ix) Applied Research: More business and market oriented courses should be introduced at the college level so that the graduates are quickly and gainfully employed in their relevant fields.

\section{THE PROBLEMS FACING THE RESEARCH INSTITUTIONS3:}




\section{A.E.R.C.}

The AERC which was founded in the early 1970s with the assistance of the Ford Foundation and the Government of Sindh has during the last two decades emerged as a major centre of teaching and research in Economics in the country. In addition to undertaking high quality research in the areas of public finance, agricultural economics and urban development, the Centre has also conducted an MAS/M.Phil programme in Economics and from well known economists in the country. It has also tried to lay the foundation of peer participation in the decision-making process and peer review of the academic research undertaken by the Centre.

In recent years, AERC has seen a rapid erosion of its research staff who have left for other more remunerative jobs abroad or elsewhere in the country. The number of Ph.D staff members in AERC has declined to four from its peak level of 13 in the past. Lately, the Centre has experienced serious competition from a number of directions including private schools and universities as well as foreign donor agencies, commercial banks, investment firms and private consultancies and research institutions. Recently, the University of Karachi has also tried to regularize the service structure of the core staff of the Centre who are employed on the basis of the recurring annual grant from the UGC. The salary schemes of the research staff are broadly in line with those of the University teachers. The autonomy of the Centre has also been compromised to some extent and has resulted in some degree of interference from the University administration. The core research staff of the Centre also can supplement its income by a substantial amount by participating in contractual research undertaken by the Centre. In addition, the Centre has created a core research fund which allows a faculty member to undertake research in his own area of interest and get compensation roughly equalling to that from contractual research. This is an innovation which needs to be strengthened by the Centre and emulated by other research institutions.

The Centre depends heavily for its success on two areas. The first, the availability of researchers and to retain them in the face of strong competition from outside. Secondly, the Centre needs to sustain its Masters/M.Phil programme in applied economics. The strength of the faculty in the Centre works as both a cause and effect of the success in the two major areas. In recent years, the Centre seems to have experienced considerable difficulties on both these counts which has consequently resulted in the depletion of its faculty. A more intangible reason for the progressive downside of the centre has been the erosion in its top leadership and lack of harmony in the aims and objectives of the Centre as perceived by its members. The assertion of bureaucratic authority and the delusion of the Centre's autonomy and peer participation have also resulted in the Centre's present decline.

\section{P.I.D.E.}

The Pakistan Institute of Development Economics is the country's premier economic research institution with a history of more than four decades.4 However, it had to be re-established in 1972, after the creation of Bangladesh and relocated in the Quaid-i-Azam University Campus, Islamabad. During the quarter-century of its rebirth, the Institute has experienced many changes in the strength of its research staff. The Table 3 below shows that a rapid increase in its staff occurred after the resumption of its activities in 1972, with only a skeleton staff which returned from Dacca and some trainees abroad who joined it later.

Table 3: Changes in the Research Staff, 1973-95

\begin{tabular}{|c|c|c|c|c|c|c|c|c|c|c|c|c|}
\hline Years & \multicolumn{4}{|c|}{ Non-Ph.Ds. } & \multicolumn{4}{|c|}{ Ph.Ds. } & \multicolumn{4}{|c|}{ Total } \\
\hline & A & B & C & D & A & B & C & D & A & B & C & D \\
\hline
\end{tabular}




\begin{tabular}{|c|c|c|c|c|c|c|c|c|c|c|c|c|}
\hline 1973 & -- & -- & -- & -- & -- & -- & -- & -- & 29 & -- & -- & -- \\
\hline 1974 & -- & -- & -- & -- & -- & -- & -- & -- & 20 & -- & -- & -- \\
\hline 1975 & -- & -- & -- & 46 & -- & -- & -- & 7 & 18 & -- & -- & 53 \\
\hline 1976 & 4 & 1 & 3 & 49 & 0 & 1 & $1(2)$ & 8 & 4 & 1 & 5 & 57 \\
\hline 1977 & 8 & 7 & 0 & 49 & 2 & 0 & $3(1)$ & 11 & 10 & 7 & 3 & 60 \\
\hline 1978 & 3 & 6 & -4 & 45 & 1 & 1 & $1(1)$ & 12 & 4 & 7 & 3 & 57 \\
\hline 1979 & 12 & 3 & 5 & 50 & 1 & 1 & $4(4)$ & 16 & 13 & 4 & 9 & 66 \\
\hline 1980 & 7 & 5 & 0 & 50 & 1 & 1 & $2(2)$ & 18 & 8 & 6 & 2 & 68 \\
\hline 1981 & 11 & 8 & 1 & 51 & 0 & 2 & $0(2)$ & 18 & 11 & 6 & 1 & 69 \\
\hline 1982 & 7 & 3 & 3 & 54 & 0 & 1 & $0(1)$ & 18 & 7 & 4 & 3 & 72 \\
\hline 1983 & 0 & 8 & -8 & 46 & 0 & 1 & -1 & 17 & 0 & 9 & -9 & 63 \\
\hline 1984 & 12 & 5 & 6 & 52 & 1 & 3 & $-1(1)$ & 16 & 13 & 8 & 5 & 68 \\
\hline 1985 & 8 & 8 & -1 & 51 & - & - & $1(1)$ & 17 & 8 & 8 & 0 & 68 \\
\hline 1986 & 9 & 0 & 8 & 59 & 0 & 2 & $-1(1)$ & 16 & 9 & 2 & 7 & 75 \\
\hline 1987 & 9 & 3 & 5 & 64 & 0 & 0 & $1(1)$ & 17 & 9 & 3 & 6 & 81 \\
\hline 1988 & 1 & 4 & -5 & 59 & 0 & 2 & $1(2)$ & 18 & 1 & 5 & -4 & 77 \\
\hline 1989 & 6 & 7 & -2 & 57 & 1 & 2 & $1(1)$ & 19 & 7 & 8 & -1 & 76 \\
\hline 1990 & 4 & 5 & -1 & 56 & 1 & 2 & 0 & 19 & 5 & 6 & -1 & 75 \\
\hline 1991 & 1 & 5 & -4 & 52 & 0 & 3 & -2 & 17 & 1 & 7 & -6 & 69 \\
\hline 1992 & 1 & 2 & -4 & 48 & 0 & 2 & $2(3)$ & 19 & 1 & 3 & -2 & 67 \\
\hline 1993 & 0 & 1 & -1 & 47 & 0 & 3 & -3 & 16 & 0 & 4 & -4 & 63 \\
\hline 1994 & 0 & 3 & -4 & 43 & 0 & 1 & $0(11)$ & 16 & 0 & 4 & -4 & 59 \\
\hline 1995 & 0 & 4 & -6 & 37 & 0 & 1 & $1(2)$ & 17 & 0 & 5 & -5 & 54 \\
\hline
\end{tabular}

Note: $\quad$ Those who obtained Ph.D. during service are reported in parenthesis

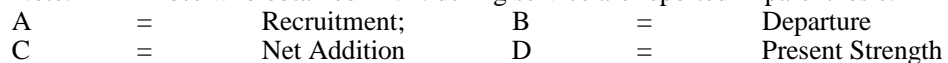

Net Addition = A - B - those who obtain Ph.D during service

However, the rapid increase in the research staff plateaued by the end of the 1970s when the first regular Director of the Institute, the late Mr. M. L. Qureshi was replaced in 1979 by Dr. S.N.H. Naqvi who retired in 1995.In the first half of the latter's 16-year tenure, the Institute's research staff strength again experienced rapid growth, rising from 66 to 81 in 1988 when it achieved its peak level. Since the early 1990s, however, the Institute' research staff has experienced steady erosion in its strength which by now has been reduced to the level of 1975.During the 20-year period, 1975-95, as many as 124 research staff members have left the Institute, while an almost equal number have been recruited. This seems to be a rather high rate of turn-over.

The situation in regard to the Ph.D. staff, who constitute the core of the research strength of the Institute, has also varied considerably over time. Although their number increased from 7 in 1975 to 17 in 1995, it has remained almost constant since 1980 at around 18. What is even more significant is the high number of Ph.Ds who have left the Institute during the period. According to Table 3, a total of 24 Ph.D.s have left, almost half of them since 1988. This erosion of Ph.D. strength has been offset almost exclusively by the retraining of non-Ph.D. staff, rather than by infusion of new Ph.D.s, which has been a minor source of replenishment, especially in the second half of the period under review. The prospect of further deterioration in the strength of the Ph.D. staff are now greater, as the opportunities for higher training dry out and as the number of junior staff members declines as a result of the ban on further recruitment. Indeed, the ratio of junior research staff, represented by those without Ph.D.s, to those with Ph.D.s has declined from 6.57 in 1975 to 2.18 in 1995. This has serious adverse implications for the Institute's role of providing on-the-job training to younger economists who can then enroll in Ph.D. programs in foreign universities. Since very few foreign-trained Pakistani Ph.D.s are returning home and many resident Pakistani Ph.D.s are seeking jobs abroad, this has rather disturbing implications both for the P.I.D.E. and other institutions. 


\section{THE STATE BANK OF PAKISTAN's RESEARCH DEPARTMENT5}

The Research Department of the State Bank of Pakistan has recently been re-organized into three major areas, (i) General Economic Research, (ii) Monetary and Fiscal Research (iii) International Economics Research. The work in all these areas is overseen by the Economic Advisor of the Bank, a post which is currently lying vacant. The three research sections work more or less independently of each other under the overall supervision of the Chief Economic Advisor and the Governor of the State Bank of Pakistan. The General Economic Research Section has three areas of responsibility: (a) real sector investment (b) macro modeling and forecasting; (c) Islamic economics. The research department has recently recruited research officers after considerable lapse of time. These young officers selected from all over the country are possibly among the best graduates produced by different universities of Pakistan. They seem to be highly motivated. However, there is a general lack of research environment and even those who like to do research are over burdened with routine work. The research department, like all other departments in the bank, has a bureaucratic structure which lacks the motivation for undertaking research. The training programmes instituted recently under the auspices of IMF narrowly focused on financial programming and are not helpful in the development of a worstyle research. The higher echelon of the Bank including the Governor seems to be conscious of the need for undertaking independent research in the Bank. However, the pressures of being the advisors to the government on monetary and financial matters, and of regulating banking system a long period of government intervention has become inefficient and the portfolio has become infected with unpaid loan, leaves it little time and energy for paying attention to research. Under these circumstances, the Bank seems to have adapted the strategy of getting outside consultants to undertake research for specific issues, (e.g. inflation and domestic savings) who work in the bank for specified period of time. However, this does not result $\mathrm{n}$ any spin of attack which would benefit in strengthening the research capability in the bank or in the country at large.

Despite the granting of the degree of autonomy to the State Bank, the primary function of the research department of the Bank seems to be that of a government department which is constantly entrusted with the preparation of the briefs. Variety of ministries and government departments. The depletion in the technical staff of economic ministries and departments had the impact of using the research department of the State Bank to the point where it cannot engage in any field of research work on issues of concern in the Bank.

The Bank employs a substantial number of economists in its three Research Departments. In all, there are about 70 officers working in these Departments. At present, the Department has only three Ph.Ds and 15 who have post-M.A. degrees (Foreign Masters degree, M. Phil. or M.B.A.). The rest of the staff have local M.A. degrees, a majority with a vintage that is five or more years old. Given the low and deteriorating quality of the M.A. Economics degree (which in most foreign universities is treated as no more than a first degree) in our universities, the bulk of the research staff is in need of a substantial degree of upgrading of skills in economic analysis. At present, there exist few opportunities for the staff to do this, except through on the job training, which is often confined to routine computational work or writing reports in a rigid, repetitive format. 
Thus the present makeup of the research staff is quite bottom heavy, while lacking in high quality leadership. For some years, the Bank has been unable to fill the post of Deputy Governor (Policy) and Economic Adviser and their roles have been performed by stopgap arrangements. The Bank management does seem to be aware of the problem and has periodically tried to address it. Its approach, however, seems to be conditioned by its desire to get quick and assured, if mediocre, results, rather than addressing the more serious underlying problems which could yield potentially larger benefits.

While the weaknesses in the composition of staff will take considerable time to remedy, the better utilization of existing human resources, which are quite considerable both in quality and quantity, offers a more feasible avenue for improving the current level and quality of the Bank's research output. As the literature on growth tells us much of the growth in the modern world has occurred not through increases in factor inputs, but by such residual factors as innovation, organization and environment. It is in this context that the current environment for research in the Bank is in need of a great deal of improvement. Good research is very often the product of interaction, team work and a sense of belonging, as well as fair competition, among those working in an institution. These observations are valid, to a considerable extent to other

\section{iv) The Institute of Development Studies}

It has emerged from the Board of Economic Enquiry, NWFP which functioned from 1953 to 1980 and was primarily engaged in collection of data and conduct of surveys in the rural areas of NWFP. (A similar Board existed in the Punjab and was converted into Punjab Economic Research Institute (PERI), Lahore.) The conversion was facilitated by a USAID funded programme called TIPAN which functioned from 1984 to 1994. The Institute's staff consisting of about a dozen researchers, half of them women, the majority of whom had Masters Degree in Agriculture obtained through the scholarship of the USAID. In addition to doing research mainly in the area of agricultural economics, the institute conducts a teaching programme in M.Sc. Rural Development (Honors). The average enrolment in the programme since it was started in 1986-87 has been ten students per year. Thus the Institute's teaching programme enjoys a highly favourable student-teacher ratio of almost one to one. The minimum qualifications for admission to the M.Sc (Honors) programme is B.Sc. Agriculture from any agricultural university of Pakistan. The programme also competes with M.Sc. (Agricultural Economics) conducted by the Agricultural Economics Department, Peshawar University. There is some ambiguity regarding the overlap between the two programmes being run on the same campus. It was emphasized by the staff of IDS that this programme was more broadly based social science and rural development programme than the agricultural economics programme which centres more on core economic issues. Both the Agricultural Economics and IDS are members of Faculty of Rural Social Sciences in the University which consists, apart from these two disciplines, agricultural extension, Pakistan studies and mathematical science departments. The Director and staff of IDS felt that the courses introduced by them generally had centered to good job opportunities after graduation.

A new generation of research institutes with a somewhat different orientation than the old established research organisations discussed above, have emerged in the 1990s. Among these, the 
Sustainable Development Policy Institute (SDPI), Islamabad, the Social Policy Development Centre (SPDC), Karachi and the Mahbubul Haq Human Development Centre (MHDC) deserve particular mention. They differ from the older research institutes in the following way;

(a) They do not receive any direct funding from the Government, but depend either on endowments, consultancy contracts or donor support. They have their own Governing Boards, with no ex-officio representation.

(b) They are small in size, with very few core staff members, and their work depends on domestic and external consultants. Their salary or total emoluments structure is closer to international agencies than domestic employers.

(c) They are concerned mostly with social development, environment, gender and other emerging issues in development. They generally do not undertake basic research on core economic issues, but engage in advocacy roles, information dissemination and policy research.

Although these newer institutions have not yet directly impacted on the supply or demand for economists as much as the older institutions have done, their presence is to be welcomed as they provide not only stimulus to new ideas, but can also have a favourable influence on the older institutions in terms of organisation, staff relations and peer interactions, which the latter are greatly wanting in.

\section{NEED FOR SOME BOLD AND OVERDUE INITIATIVES}

The lack of a working relationship between the research institutes and the universities has proved detrimental to the interests of both, as well as to the development of ERS generally. The fostering of a symbiotic relationship between the two will have considerable social benefits, which have been frittered away in the past due to considerations of the turf and institutional and personal rivalries. The minimization of the latter through mutual discussions for cooperative arrangements is likely to yield rich dividends and lead to the reinvigoration of the economics profession. In this regard, the two major research institutes, the Pakistan Institute of Development Economics, Islamabad and the Applied Economic Research Centre, Karachi, which were both established with substantial assistance from the Ford Foundation and receive large grants from Federal and Sindh Governments, respectively bear significant responsibility. The Research Department of State Bank of Pakistan was also in the past known for its ability to produce able economists and quality research, although largely for the internal use of the Bank, could also play a useful role. The State Bank, with its recently acquired autonomy and considerable discretionary funds at its disposal, should have a special interest and responsibility in promoting economic education and research in the country which would enhance the country's capability for better economic management.

Educational institutions and research organizations must cooperate with each other more closely than in the past in applied training of the students. At present most of the faculty members in 
universities are only marginally involved in undertaking research. They often complain that they have too much teaching load and too little incentive to undertake any research. In particular, there is a strong case for much closer collaboration between the Economics Department of the University of Karachi and the Applied Economics Research Centre (AERC), although some of the teachers are involved in research projects undertaken at the Centre. The AERC also provides the Department teachers to occasionally teach in their M.Phil Programme. There is, however, a lack of a structured relationship between the department of Economics and the AERC which often gives rise to a tension between the two entities. There has been a history of lack of a close relationship between the Centre and the Department of Economics largely as a result of personality clashes and the disparity between the environment received by the staff of the faculty. There seems to be no attempt to reduce the tension between the Department and the Centre with a view of profiting from each others experience and promoting both teaching and research. A similar situation has existed in varying degrees over the years between the Quaid-I-Azam University and the P.I.D.E. The lack of such cooperation leads to underutilization and suboptimal use of resources at a time when the country faces an extreme shortage of overall resources. If these problems could be ironed out, there is a likelihood that two first-rate graduate programs in economics, with the potential of awarding Ph.D. degrees could result.

There is a strange feeling that somehow, we are back to where we started two decades ago. The problems identified by Professor E.A.G. Robinson (1967) and Professor J.P. Lewis (1975) still persist naciously.(see Table A-I). The problem currently being faced by teaching and research institutions in economics have reached crisis proportions for some time. The observation made by Professor John Perry Lewis at the end of 1975 that "compared with country's needs and inherent capabilities, the state of Pakistani economics is really quite disgraceful; it is in crisis"6 is perhaps more valid today than it was two decades ago when the economic profession had started showing some signs of renaissance.

If the economic teaching and research is not to become marginalized, some bold steps to revive it from its present predicament will have to be taken. In view of the over-centralized and bureaucratized nature of our educational system, the first thing that is needed is to free these institutions from their official shackles There is a need to give university and other non-official economists and researchers a voice in the way in which the institutions can be rebuilt and energised.

There is also a need for decentralizing the administration of educational institutions and research institutes and entrusting them to peer groups for their revival. Instead of the current practice of giving annual budgetary grants to run these institutions, the government as well as interested domestic and foreign donors should create a foundation or trust for carrying out educational and research projects in the economic field. Almost all developing countries have created autonomous social science research foundations which provide funding for research programs drawn and approved by peer groups. The trust should receive contributions either in lump sum intended for disbursement over not less than three to five years or commitment to provide annual contributions over period of similar duration. The trust could then disburse them to educational and research institutions either as research funds or for creation of endowed chairs or for support of research projects. The governance of such trust should be wholly Pakistani with a majority of academics and researchers in the governing board. The trust itself should not operate as a research or teaching organization but should fund and monitor research and academic activities. The trust's concept should also be replicated at the individual institute or university 
level to mobilise more public funds for education. The trust idea for raising and utilizing public funds for the social sector, helps overcome the current concerns about the credibility, responsibility and prudential behaviour of the Government. Despite the growing awareness and realization among people, including the lay public, about the country's poor image in terms of human resource and social development as well as the willingness and the ability, especially among the affluent, these concerns have hindered generous donations to education. In order to inspire public confidence, such funds should be channeled through endowments to autonomous public institutions, with independent governing boards. The Draft National Education Policy (1998-2010) had recommended the creation of an Endowment Fund for Research7, without specifying its modalities, but the idea seems to have been dropped from the Final Draft.

There is also need for periodic review of the research needs and agenda in the field of ERD. Pakistan is, perhaps, among the few countries in the world which does not have a national body to promote, fund or otherwise facilitate the conduct of social science research and teaching in a systematic way. As a result, the quantity, quality and diversity of research output on economic and social issues in Pakistan compares very unfavourably with those in India or Bangladesh with whom we have had a shared political past. Greater collaboration and more frequent interaction among the research and academic communities will lead to the enhancement in the quality of research output in the country.

\section{Faculty Improvement: Brain Drain and Overseas Training}

As the results of the preliminary survey of economic and research institutions reveals the most endemic problem facing them is the scarcity of well trained staff. As the university and the research institutes have been unable to maintain a sustainable supply of qualified staff, who were perennially wooed by outside temptations of joining the Pakistani economic profession has become entrapped in a particularly poorer pattern of leakages abroad. The Pakistani foreign trained economists working in Pakistani universities and research institutes are greatly outnumbered by those working with the World Bank, IMF, and other international agencies, both abroad and in Pakistan. This constant leakage of trained Pakistani economists needs to be plugged both by taking bold administrative measures to induce those who have left these institutions to return back to them, not only by offering attractive salary but also the congenial, less bureaucratic and more peer centred work environment. There is also the need to retain those who have returned from abroad by giving them greater responsibility and providing them opportunity for self-improvement. For this purpose, a special fund may be created to plug this leakage through various incentives. The creation of a minimum mar of academics and researchers in a given period could also succeed in strengthening the institutions on a sustained basis. There is also a need to recreate the environment in which scholars feel that they receive recognition and respect for their research academic achievements, even without being directly useful in policy-making.

\section{GAPS IN THE STUDY AND NEED FOR FURTHER RESEARCH}

As pointed out in the introduction, this paper is the product of a preliminary study into the problems of teaching and research in economics in Pakistan and does not pretend to present definitive or startling results. It does, however, point to a number of inadequacies in the present institutional 
arrangements and offers some suggestions for improvements in them. The best it can hope for is that it will stimulate serious discussion on these issues and would become a precursor of a more comprehensive and well-organised study which would go into many of the details that the present effort has been unable to capture.

The discussion in this paper has centred on universities and research institutes which directly contribute to the production of better economists in the country. However, the concentration on the postgraduate degree program has deflected attention from the much more important task of producing good undergraduates at college level. This study did not focus on degree and intermediate colleges with the academic standard of which appears to have deteriorated even more than in the universities, indeed the present trends towards private education has adversely affected the standard in public institutions which provide the bulk of students to the universities. Unless considerable resources and attention are diverted to the undergraduate colleges in the public sector, the improvement in the universities will be that much more difficult to achieve. The paper has also not been able to assess the demand for economists and the changes in such demand that have occurred in the past and that are likely to occur in the future.

A more comprehensive study will also have to focus on the reservoir of expatriate economic experts which must be tapped not simply as a way of short-term alleviation of scarcity of economic expertise in the country but also by giving them a role in rebuilding the institutions of research and advanced studies in the country. 


\section{References}

Robinson, E.A.CG (1967), The Problems of Teaching Economics in Pakistan, Pakistan Institute of Development Economics, May.

Siegfried, J.J., R.L. Bartlett, W.L. Hansen, A.C Kelly (1991) "The Economics Major: Can and should we do better than a B-", American Economic Review, paper and proceedings, Vol.8, \#.2 May: (20-31).

Lewis, J. P. (1975), Economics in Pakistan and the Ford Foundation, (mimeograph) PIDE, November.

Krueger, A.O. et. al. (1991), "Report of the Commission on Graduate Education in Economics", Journal of Economic Literature, September, vol. XXIX, \# 3, (1035-1053).

Hansen, L. W. (1991), "The Education and Training of Economics Doctorates" Journal Economic Literature, September Vol. XXIX, \# 3, (1054-1087).

Kabra, K. N. (1996), "Accountability of Higher Education", IASSI Quarterly, January - June, Vol. 14, \# 384, (52-60).

Kasper, H., et. al. (1991), "The Education of Economists: From Undergraduates to Graduate Study" Journal of Economics Literature, September, Vol. XXIX, \# 3, (1088-1109). 


\section{Appendix A:}

Following educational and research organizations were visited to conduct interviews:

1. Lahore University of Management Sciences (LUMS), Lahore.

2. Government College, Lahore.

3. Punjab University, Lahore.

4. Punjab Economic Research Institute (RERI)

5. Bahauddin Zakariya University.

6. Institute of Development Studies, Peshawar.

7. University of Peshawar, Peshawar.

8. University of Karachi, Karachi.

9. Applied Economic Research Centre (AERC), Karachi.

10. State Bank of Pakistan, Karachi.

11. Gomal University, D. I,. Khan.

12. Quaid-I-Azam University, Islamabad.

13. Arid University, Rawalpindi.

14. Pakistan Institute of Development Economics, Islamabad

We are grateful to all the individual in these organization for their invaluable contribution. 


\section{End Notes}

1 These disciplines now include demography, social anthropology, econometrics and human development

2 This section is based on direct interviews with a number of universities and educational institutions. The qualitative response is summarized in Table A-1

3 The qualitative response of these organizations is summarized in Table A-2.

4 For a detailed history of the pre-1972 period of the Institute, see George Rosen,

5 This section draws upon a report prepared by Dr. S.M. Naseem for the State Bank of Pakistan while he served as a Research Advisor to the Bank and as Consultant to the Asian Development Bank during 1997.

6 John Fairy Lewis, (1975) Economics in Pakistan and the Ford Foundation, November 18, 19975.

7 Draft National Education Policy, 1998-2010, Government of Pakistan, Islamabad, 1998, Clause 9.5.30, 
Table A-1

Qualitative Indicators of Teaching of Economics

\begin{tabular}{|l|l|l|l|l|l|l|l|l|l|l}
\hline & & $\begin{array}{l}\text { Govt. } \\
\text { college } \\
\text { Lahore }\end{array}$ & $\begin{array}{l}\text { Univ. } \\
\text { of } \\
\text { Punjab }\end{array}$ & $\begin{array}{l}\text { Univ. of } \\
\text { Pesha- } \\
\text { war }\end{array}$ & $\begin{array}{l}\text { Gomal } \\
\text { Univ. }\end{array}$ & $\begin{array}{l}\text { Institute } \\
\text { of Dev. } \\
\text { Studies } \\
\text { Pesha-war }\end{array}$ & $\begin{array}{l}\text { Quaid-I- } \\
\text { Azam } \\
\text { Univ. }\end{array}$ & $\begin{array}{l}\text { Sindh } \\
\text { Agri. } \\
\text { Univ. } \\
\text { Tando } \\
\text { Jam }\end{array}$ & $\begin{array}{l}\text { Univ. of } \\
\text { Arid Agri. } \\
\text { Rawal- }\end{array}$ & pindi
\end{tabular}
Retirement Other Benefits

3. Has the quality of economic education improved Yes

4. Is there a linkage between working conditions and teaching

5. Are you satisfied with status of teaching of economics

6. Do you think teachers need further training: I) in Pakistan
ii) Abroad

7. Do you think your graduates are sufficiently trained to enter job market

8. Is there a need to develop a linkage between educational institutions and job market

9. Perception about availability of information and scholarships for higher education Inad.

10. Are you satisfied with the present curriculum in Economics

11. Change in number of teachers between 1975 and 1995

12. Change in No. of teachers with Ph.D. degree between 1975 \& 1995

13. Change in enrolment between 1975 and 1995 small

14. Student-teacher ratio

9
1

$--$

Ad Inad.

7

Note: $\mathrm{S}=$ Satisfactory, $\quad$ Ad $=$ Adequate;

Yes No Yes Yes Yes no nes

$\begin{array}{llllllll}\text { Yes } & \text { Yes } & \text { Yes } & \text { Yes } & \text { Yes } & \text { Yes } & \text { Yes } & \text { Yes }\end{array}$

nad.

Yes

No Yes

Yes

No

No

No

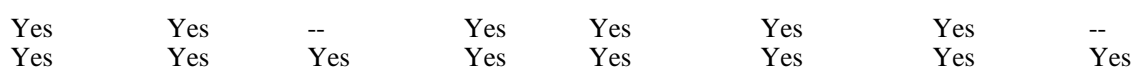

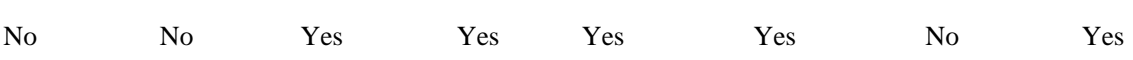

Yes

(

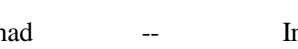

$\begin{array}{lllllll}\text { Yes } & \text { No } & \text { Yes } & \text { Yes } & \text { Yes } & \text { No } & \text { No }\end{array}$

Declined increased increased -- $\quad$-- $\quad$ increased $\quad$ No change ---

No change increased no change -- $\quad$ increased increased increased --

increase

increase -- $\quad$-- $\quad$ increased

increased

-.

increased

declined

declined

increased

increased --

Inad = Inadequate 
Table 2-A

Qualitative Response of Employers

\begin{tabular}{|c|c|c|c|c|c|}
\hline & & SBP & $\begin{array}{l}\text { Uni. of } \\
\text { Peshawar }\end{array}$ & $\begin{array}{l}\text { IDS, } \\
\text { Peshawar }\end{array}$ & PIDE \\
\hline \multicolumn{2}{|c|}{ Are you satisfied with the performance of Research Staff } & Yes & Yes & Yes & Yes \\
\hline \multirow{2}{*}{\multicolumn{2}{|c|}{$\begin{array}{l}\text { Is there a need for further training in : I) Pakistan Yes } \\
\text { ii) Abroad }\end{array}$}} & Yes & Yes & Yes & \\
\hline & & Yes & Yes & Yes & \\
\hline \multirow{2}{*}{ Length of required training: } & & Yes & Yes & Yes & Yes \\
\hline & ii) Long-term & -- & Yes & Yes & Yes \\
\hline \multicolumn{2}{|c|}{ Is on-the-job training program available in your organization } & Yes & No & Yes & Yes \\
\hline \multicolumn{2}{|c|}{$\begin{array}{l}\text { Is there a need to develop interaction between educational } \\
\text { institutes and job market }\end{array}$} & Yes & Yes & Yes & Yes \\
\hline How many researchers have left during 1975-95 & 14 & -- & -- & $124 *$ & \\
\hline Incentive structure in your organization & attractive & -- & -- & attractive & \\
\hline Has the research staff increased during 1975-95 & Yes & Yes & Yes & Yes & \\
\hline Has the research staff with $\mathrm{Ph}$. D. degree increas & Ideclined & -- & Increased & Yes & \\
\hline
\end{tabular}

Notes: $\quad * \quad$ Out of these 124 researchers, 6 retired/expired and 12 were dismissed.

SBP $=$ State Bank of Pakistan

IDS = Institute of Development Studies, Peshawar.

PIDE $=$ Pakistan Institute of Development Economics. 